\title{
Qualitative And Comparisonal Evalution of Dimentionas of University Professors through 360 Digree Thechnique
}

\author{
Mostafa Jafari \\ Assistant professor of management department, \\ university of zanjan, Zanjan.Iran \\ Mina Afshari \\ Master student of Abdor Rahman Sufi Razi Higher Education Institute, \\ Zanjan, Iran
}

\begin{abstract}
New days , there are many evolution in knowledge of management , being of system of available is unavoidable, that absence of it is in dimension of different "s organization ,level of management, personal as one of banner of malady "s organization . Operation assess pattern degree 360 is signal of wind age operation. And in it is main development of lead quality \& development management. This process is perfect cycle, that it is windward extract all of person (supervisors, subalterns, and, coworkers) in different ways of lead $\&$ his management $\&$ operation endow uniformly and amiable. Target of this research professor operation examination with degree
\end{abstract}

Key words: degree 360 evalution technique, examination of professor \& students.

\section{INTRODUCTION}

New world changes, variety \& complexity of problems in organization have made that management execution only with information and exact statistics, for accede their aims (Javaheri zadeh at all, 2011).

Degree 360 windward is adaptation method in basis of lead quality development \&development management .this process is perfect cycle , that it is windward extract all of person (supervisors, subalterns, and, coworkers ) are doing in different ways of lead \& management \& his operation. Some of organizations are doing windward for one part of organization with systematically. Windward helps to persons, until they are comparison their impression in their office, with important logisticians conception. These are logisticians includes: coworkers, subalterns, and management, even customer, presenter \& CORPORATISM "s members. Multiple reference windward program \& degree 360 windward have produced farm operation examination process developed ways, organization checking \& customer windward (one part of perfect quality management). Systems of degree 360 windward reason currency of republicans structures\& flatter organization \&as well as in reaction to difficulties that they have developed with tradition operation management systems (Rancaspion, 2000).

Operation examination is, with method of republican's examination, that it is one lists, they are preparation of personal index, behavior\& operation. \& is contemplated emphasis factor for them, and from all of person correlate direct \& indirect in organization included: superior, coworkers, subalterns \& customer are wanted, until they are examination in basis of specified index. Examiner also as self-examiner have partnership in process results from all of 
pluralization examination given to examiner, that it is included gain distinction in any aspect , points of intensity ,and aceptive point (Iran Khodro Training Center, 2006).

Different research in examination methods, but none don't have emphasis special method, and this is emphasis of necessity, there are that in first we should examination aims and organization expectancies from operation examination, and then unto them we election adaption method. although many of researchers \& man made management, believes that ordinary more executive \& timing method ,more expedient information give for our .but this is important problem, that in this method we election with use of analytics benefit cost ,applicative method as for organization position degree 360 examination is kind of republican examination method, that in this method we prepare list of slightly adequacy, and from all of indirect \&direct persons in organization like of : superior , coworkers , subalterns , customers is wanted , until they examination his basis of signification adequacy. Tried self rater is partnership in process. Outcome results from all of examination is pluralization and aspect of reportorial is afforded to windward individual (Iran Khodro Training Center, 2006).

\section{Examination:}

\section{SCIENTIFIC BASE}

Examination, act of avail detect, part \& ambit consider any thing and estimate of avail that word, "examination" is outcome of infinitive. It is activity that its essence is didactic, socially, cultural. Accordingly with help of examination we should one comparison between aims implied, And said, off and, do with slightly results and unforeseen results about face, and then outlay to effect evaluation this results in cultural, socially, economically environment. The aim of examination is finding information for improvement process planning and in result of improvement in national, regional, local society external. Should notice to that examination only is not compttion once after that program accomplishment rather than there is always in during of examination, until it provide operation adaptation with aim of program(The educational planning process by a group of consultants UNESCO).

Examination: Evaluation process, evaluation and appraisal judgeship is process that it does evaluation and temptation and evaluation, judgeship in about operation during appointed circuit, evaluation is complex affair, for comparison between outcome results and program nominative aims. Outcome results from program can be exactly alien with what sightly (Bitarafpour, 2013).

Mack Grigor assign three chief aim for operation evaluation systems that consist of: 1- office aim that its findings use in salary nomination, elation and abate, relocation and duty end. 2The aim of information that it, s finding is adaptation facility for aware roll call. 3- Inanition aim that it use from evaluation as inanition gadget. And it made, examiners are active in planning and aims, and in cases like of republican action, adoption conferment, and participatory management in applicative currency environment (Chunk Gloria, 2002).

Many of personnel uses operation evaluation ways have censured by experts (Dolan, Shimon El, Shouler, Rental S, 1999).

\section{Methods or operation evaluation:}

There are different methods for personnel operation evaluation, that instead of one of operation can be division them(Bayerz \& ro,2008) but which method is most adaptation \& best evaluation way, aim of organization concern to personnel evaluation, and it use usually compound from different methods on personnel evaluation(Dolan \&Bolender,2007). Performance evaluation methods presented in three general categories as follows 
a) Methods of covering basis upon personnel characteristics:

-Complex standards meter method

-descriptive method

- Graphic ranking meter methods.

b) Methods upon behavior or behavior method, behavior observation meter

- Alive events recording method

- check list

- Behavior ranking meter method

- Behavior observation meter method

c) Methods results:

- Management method upon basis of aims

Programmer or balanced distinction

Other experts, in addition to the above-mentioned methods are also introduced other methods

1- Graphic ranking meter method

2- Complex standards meter method

3- Cogency election method

4- Descriptive method

5 - Alive events recording method

6- Check list method

7- Behavior ranking meter method

8- Behavior observation meter method

9- Management method upon basis of aims

10- Action standards method

11- Team examination degree 360 event method.

For many years ago that literati and researchers are uses variate methods for operation examination execution, they are profit from methods of ,upward , parallel ,by coworkers and even from self examiner, but there have built many nowadays organization in base of structures matrix , and it is not may in team, we abstract individual operation from another person. In thus condition, betterness information degree 360 windward we provide in team individual context (Chang\& et all, 2002).

Process of degree 360 windward materiel multi stage consist of: (Mack Karti, 2001)

1- Degree360 windward aim fixation: mean of degree360 windward aim fixation, that it is outcome information from process use for job path development and operation examination. Ought this goal is specified, and it is correlate with all of nominees.

2- Choice of data collection instrumentation: examination instrumentations consist of questionnaires, that it is fill in the blank by evaluators. Nevertheless, many organizations uses from interview naturally count these organizations are scanty.

3- Decision making in cases context: in this context is commendation that instead of general characteristics notice to behavior actual. clear- sighted have advanced, that examination items should upon special content, as it is decrease examination error .behaviors that they examine ,they should are issue from outlook and organization value .

4- Decision making in about of windward receivers: in this stage is fixation, windward receivers. In management literature, there is belief, that roll call should be entrant for communion .cogency communion can be impendent, and it is hazard of system affective. 
Degree 360 windward, for wealthy windward, that it is available by servitors, there is useful instrumentation in lead development programs.

5- Training of evaluator \& rated: relationship with all of outbreak nominee in degree360 windward process, it is need of design stage \& windward implement. Learn of craft is one part of this process. Training of rated is necessary in negative windward reception. Raters should be aware in examination different errors that it can be arose.

6- windward receiver, election evaluator : evaluator consist of bosses, self person, subaltern, indoor, abextra customers .

7- Questionnaire distribution: questionnaire has 2 form. in method first is pen \& paper , that evaluator use for person different behaviors examination .it is efficient method, transmit of disk to any which of evaluators ,and they can fill the questionnaire in form of electronic .

8- Windward information analyzation: in this stage is collection windward information, and provide necessary report.

9- Windward giving windward: when reports are ready, and is completion final report, windward is gives to windward receiver.

10- Process execution pursuit: windward receivers should be develop context creation, and use from windward data in development context and learning. it is necessary that windward receivers, have applied program .

11- Process repeat: there are in organization that degree 360 windward as affective, may be process, they are repeat after of receiving windward early reports. but this is process is perfectly new in many of organization, and aim of degree 360 windward adoption , in this organization is in first of degree, communion opportunity creation for personnel.

Degree360 windward, in many of these references are common with multiple references.

\section{Pillar degree 360 windward:}

Windward input information degree360 examination from one up to down one dimensional to multiple dimensional have generality (subaltern, coworkers, customers), it can be space less examination. Of this is seems mean of degree360 windward, it is applicative with space less organization oven operation. the words of ordinary that they are use for degree 360 windward , consist of : nominee examination, multiple canonical windward, perfect cycle examination, multiple reference examination, subaltern - coworker examination, team operation examination , multiple point examination (Mack Karti, 2001)

Degree360 windward, in many of these references are common with multiple reference windward. Degree 360 windward quintuple pillar consist of:

\section{Up to down examination:}

examination tradition form, that they are evaluation attendants, managements, subalterns, and as yet it is important part from degree360 windward process, that it can be array informative information for roll call. In this kind of evaluation, there are chief four, that it can be reliable reference for windward. The reference simplest \& closest to roll call is immediate superior, and «matrix management », « foregone immediate management », and another chief are communion also in this evaluation (Johns \& Burly, 2000).

\section{Down to up evaluation:}

This is one of degree360 windward process inception contraption; that it is array context to ultra-hand.in subaltern's evaluation or up to windward, subalterns are evaluation supervisor and management operation from multiple dimensions, and they are array evaluation result to original one. Up to down windward as one element from degree360 windward porrect process, 
and also it is an important process, that it is help to development organization \& roll call (Johns \& Burly, 2000). .

\section{Coworkers windward:}

In model of degree360 windward, coworker's windward is array degree180 lookout in person operation evaluation. Coworkers windward, by "KEN" \&"LAVER" is defined such: "team communion process from roll call that it is judgeship about man, as any of them, they are covering of unique behavior, characteristics, or, achievement ".

\section{Self-evaluation:}

It has indication, that is intensive of it, man is evaluation self operation. In this process, man is as evaluation reference. differences important between tradition evaluation \& degree360 windward, tradition arrive, it has only one evaluation reference, when as degree360 windward operation covering multiple reference, accordingly it is more perfect from tradition arrive . this method can be realize with notice to organization values, facility of undertaking evaluation aims all of coworkers, \& also consequence like of spatial with high communion, development need evaluation, team action formation, $\&$ and in result notice to customer \& duty quality, these results are in universal class , \& it makes that it be as development instrument very vast (Moshref Javadi).

\section{Degree 360 windward currency reason:}

Multiple evaluation in 1980, it is common in organization, as one development instrument, it is use in form of splay. They are noticeable, up to down evaluation \&coworker's evaluation, in 1970 \& end of 1980. But soon end of 1990, that degree 360 is demotic. In end 1980 many Books are edition in context of multiple reference, that it " $s$ doing result of researches, that it is by" contrary lead center in Grinbor". In base of these researches, that they are get three research (Mirchi, M; 2009).

1- Windward of key one element in development \& characteristic \& vocation.

2- Many of efficient management, are learners .scilicet, effective management, are encourage development \& learning season.

3- Many of roll call are operant in environment with lean windward.

\section{TARGET COMMUNITY}

In this research is, evaluation aim \& analogy masters with degree360 materiel, and, in this research three from base science university \& Zanjan global university ore society of aim. Exemplum society: our exemplum society are collegians, masters, \& team management, university chief. Exemplum content: numbers of exemplum society are 144. Sampling method: method of sampling member's selection is dung accidental. Conversional: evaluation conversional with degree 360 materiel. Components: they are masters, university chief, didactic adjutancy, \& team's management. In questionnaire following it has design down question. 


\begin{tabular}{|c|c|}
\hline Variables & Components \\
\hline Self-evaluation & $\begin{array}{l}\text { 1. Subject taught in the lesson plan } 2 \text {. To inform students about } \\
\text { educational goals } 3 \text {.Clear expretion } 4 \text {. The use of class time } 5 \text {. } \\
\text { Students participate in classroom activities } 6 \text {.The intelligibility } \\
\text { of their explanations for students } 7 \text {. The use of varied teaching } \\
\text { methods 8.Exam questions and questions designed according to } \\
\text { the previous edition } 9 \text {. Scientific information } 10 \text {. The researcher } \\
\text { 11. Artbat Suitable for students } 12 \text {. Good communication with } \\
\text { colleagues } 13 \text {.Criticism of } 14 \text {. Accountability }\end{array}$ \\
\hline Masters coworkers & $\begin{array}{l}\text { 1. Artbat Suitable for students } 2 \text {. Good communication with } \\
\text { colleagues } 3 \text {. Criticism of } 4 \text {. Collaborate with team members in } \\
\text { educational activities 5. Professional ethics } 6 \text {. Cooperation in } \\
\text { accepting courses offered in group 7. Share with colleagues } \\
\text { Capabilities } 8 \text {. Mutual understanding and cooperation in } \\
\text { educational and research activities cover } 9 \text {. To -date scientific } \\
\text { information. 10.Collaborate with team members in research } \\
\text { activities }\end{array}$ \\
\hline chief \& didactic adjutancy & $\begin{array}{l}\text { 1. Shrkt in educational activities 2. Participate in research } \\
\text { activities 3. In collaboration with the Research Department } 4 \text {. } \\
\text { Communication with students 5. Good communication with } \\
\text { colleagues } 6 \text {. Observe Islamic method 7.Participate in } \\
\text { educational and research activities } 8 \text {. Adhere to the regulations } \\
\text { and training regulations } 9 \text {.Tasks in the field of scientific advice } \\
\text { 10.Criticism of 11. Discipline and accountability }\end{array}$ \\
\hline Collegians & $\begin{array}{l}\text { 1. The lesson plans are provided compliance training } 2 \text {. } \\
\text { Professional ethics } 3 \text {. Ability to convey meaning } 4 \text {. Ability to use } \\
\text { modern methods of training } 5 \text {. New Scientific Understanding } 6 \text {. } \\
\text { Ability to communicate effectively with students } 7 \text {. Perform } \\
\text { tasks in the field of guidance and counseling } 8 \text {. Criticism } 9 \text {. } \\
\text { Lessons to inform students about educational goals } 10 \text {. } \\
\text { Discipline and accountability } 11 \text {. Involve students in classroom } \\
\text { activities } 12 \text {. Use class time for educational activities } 13 \text {. The use } \\
\text { of teaching aids } 14 \text {. understandable explanations of teachers to } \\
\text { students }\end{array}$ \\
\hline teams management & $\begin{array}{l}\text { 1. Active participation in educational environments } 2 \text {. Active } \\
\text { and effective workshops and seminars } 3 \text {. Active participation in } \\
\text { group sessions } 4 \text {. Interest and participation in research } \\
\text { activities } 5 \text {. New Scientific Understanding } 6 \text {. Comply with } \\
\text { professional ethics } 7 \text {. Ability to communicate effectively with } \\
\text { students } 8 \text {. Ability to communicate effectively with colleagues } 9 \text {. } \\
\text { A spirit of criticism } 10 \text {. The use of modern methods of training } \\
11 \text {. The ability to communicate concepts } 12 \text { Skills in science } \\
\text { education } 13 \text {. The compliance education lesson plan } 14 \text {. The } \\
\text { timely presentation of assigned tasks }\end{array}$ \\
\hline
\end{tabular}

\section{Never eless_answer questions:}

1- What is it, in your opinion important canonical three for team's funicular priority?

2- , in your opinion, which of, base canonical three for masters funicular priority?

3- In your opinion, which of canonical three that, it is master scientific quality indicant?

(Which of masters are more scientific)

4- In your opinion, with what canonical, masters are gradually adepts?

5- In your opinion, which of, canonical three, that masters are weak?

6- Which of is important, schooling location, schooling field, \& master engagement location?

7- What is important, master aspect? (Should be canonical three in master)

8- How masters should be estimate, superiors anticipation \& coworkers \& collegians \& scientific society.

instrument research : data collection instrument are via questionnaire, that question number for 22 question collegians team , 22 question self-evaluation , 18 question coworkers, 19 question chief \& didactic adjutancy\& 22question teams management. Collection method: questionnaire have provided via internet \& experts of this action. Kind of questionnaire: it is multiple switch question \& answer never less question, data have collection aspect of personal. Questionnaire credibility: credibility of it confirmation via experts of this precept \&inviolate masters. Questionnaire justifiability: questionnaire it has justifiability, and aim society election reason, easy access to it. 
Students of the Faculty of Humanities

\section{RESULTS \& FINDINGS}

Masters teaching quality measure from aspect (literate university collegian)

Result 1 - They are adaption 56/4 percent learning master from with arrayed lesson design , $\&$ also 60.6 percent mean conduction ability masters to learners , and also 60.6 percent from masters are use evaluation\& also 60.6 percent from masters are exposition didactic aims for collegian ,\&60.6 percent from masters are use evaluation \& didactic new methods , \& also 68.2 from masters are use of variety didactic methods \& Didactic assist in facilities range \& applicative with kind of lesson and also 57 percent from masters are used scientific new professional ,and also 60.6 percent from masters are use of class time for didactic activity , up to 58.6 percent from collegian by masters are communion in class activity , and also 60 percent from masters comment $\mathrm{s}$ are clear\& intelligible for collegians .

Result 2- 50/2 percent from masters are regards professional morality \& Islamic method ,and 74.2 percent from masters are transferable,$\&$ also 52.4 percent from masters have adaptation relationship establishment ability with collegians in didactic environment, and also 62 percent from masters are doing oneself duty in guidance context \& scientific council ,and also 60.6 from masters are array regard, responsibility, hard worker, in doing duties \& responsibilities. 


\section{Result 3-}

\begin{tabular}{|c|c|}
\hline Variables & Components \\
\hline $\begin{array}{l}\text { 1. Prioritization criteria groups } \\
\text { 2. Prioritization criteria professors }\end{array}$ & $\begin{array}{l}\text { 1. The first criterion: } 54.54 \% \text { of moral behavior }-45.45 \\
\% \text { of scientific dimensions ; The second measure: } 37 / 5 \\
\% \text { of moral behavior }-62 / 5 \% \text { of scientific dimensions ; } \\
\text { And third criteria: } 75 \% \text { of moral behavior }-25 \% \text { of } \\
\text { scientific dimensions } \\
2 \text { The first criterion: } 52 / 63 \% \text { of moral behavior - } 36 / 84 \\
\% \text { of scientific dimensions - } 10 / 52 \% \text { educational } \\
\text { dimensions ; The second measure: } 68 / 42 \% \text { of scientific } \\
\text { dimensions - } 26 / 31 \% \text { of moral behavior }-5.26 \% \text { of the } \\
\text { research dimension; ; And third criteria: } 66.66 \% \text { of } \\
\text { moral behavior }-33.33 \% \text { of scientific dimensions }\end{array}$ \\
\hline $\begin{array}{l}\text { 3. Scientific quality criteria } \\
\text { 4. Strong teachers. myarhay }\end{array}$ & $\begin{array}{l}\text { 3. The first criterion: } 44 / 44 \% \text { of Educational dimensions } \\
-27.77 \% \text { of scientific dimensions - } 16 / 66 \% \text { of moral } \\
\text { behavior - } 11 / 11 \% \text { of the research dimension; The } \\
\text { second measure: } 56 / 25 \% \text { of scientific - Research } \\
\text { dimensions - } 31 / 25 \% \text { of Educational dimensions and } \\
12 / 5 \% \text { of moral behavior; And third criteria: } 53 / 84 \% \text { of } \\
\text { scientific - Educational dimensions - } 46 / 15 \% \text { of moral } \\
\text { behavior } \\
4 \text {. The first criterion: } 81 / 25 \% \text { of scientific - Research } \\
\text { dimensions - } 18 / 75 \% \text { of moral behavior; the second } \\
\text { measure: } 60 \% \text { of scientific - Educational dimensions - } \\
26 / 66 \% \text { of moral behavior - } 13 / 33 \% \text { of Research } \\
\text { dimensions; And third criteria: } 72 / 72 \% \text { of scientific } \\
\text { dimensions - } 27 / 27 \% \text { of moral behavior. } \\
5 . \text { The first criterion: } 50 \% \text { of moral behavior }-50 \% \text { of } \\
\text { scientific - Research dimensions ; the second measure: } \\
50 \% \text { of moral behavior - } 50 \% \text { of scientific dimensions; } \\
\text { And third criteria: } 55 / 55 \% \text { of moral behavior - } 44 / 44 \% \\
\text { of scientific - Research dimensions }\end{array}$ \\
\hline $\begin{array}{l}\text { 6.Prioritize based on the degree and location of } \\
\text { education and place of employment }\end{array}$ & $\begin{array}{l}\text { 6. The first criterion: } 56.25 \% \text { of field of study and } \\
43 / 75 \% \text { of education place; the second measure:53/84 } \\
\text { of Place of employment }-30 / 76 \% \text { of education place and } \\
15.38 \% \text { of field of study; And third criteria: } 41 / 66 \% \text { of } \\
\text { Place of employment - } 33 / 33 \% \text { of field of study; and } \\
25 \% \text { of education place }\end{array}$ \\
\hline 7. Important criteria for the Master & $\begin{array}{l}\text { 7. The first criterion: } 88 / 23 \% \text { of dimensions cover - and } \\
11 / 76 \% \text { of moral behavior ; the second } \\
\text { measure: } 78 / 57 \% \text { of dimensions cover - and } 21 / 42 \% \text { of } \\
\text { moral behavior ; And third criteria: } 66 / 33 \% \text { of } \\
\text { dimensions cover - } 33 / 33 \% \text { of moral behavior }\end{array}$ \\
\hline $\begin{array}{l}\text { 8. Measures to meet the expectations of superiors and } \\
\text { colleagues and students and the scientific community }\end{array}$ & $\begin{array}{l}\text { 8. The first criterion: } 38 / 46 \% \text { of scientific dimensions - } \\
30 / 76 \% \text { Relations between teachers and students - } \\
\text { 15/38\% of moral behavior; } 7 / 69 \% \text { of Research } \\
\text { dimensions }\end{array}$ \\
\hline
\end{tabular}

\section{Students of the School of Mathematical Sciences}

Masters teaching quality meter from aspect of down to up (sciences collegians)

Result 4- 40,6 percent are adaptation from didactic masters with are array lesson plan, and also 54.4 percent from masters ability of mean conduction to learners ,\&also 53.2 percent from masters are use didactic aims for collegians , and 54 percent from masters are use evaluation \&didactic new methods , and also 56.6 percent from masters are use of variety didactic methods and didactic facilities in facilities confine and applicative with kind of lesson and also 49.2 percent from masters are familiar with professional and scientific news , and also 46,6 percent from masters are use of class time for didactic activities, and also 46 percent from collegians is communion by masters in class activities , and also 46.6 percent from masters explanation are clear \& intelligible for collegians.

Result 5 - 34.6 percent from masters are observe vocation morality \& Islamic methods ,and 55.2 percent from masters are transmissible , and also 39.2 percent masters are adaptation relationship establishment ability with collegian in didactic environment $s$, and also 44percent 
from masters are doing his duties in guidance context \& scientific council , and also 54/6 percent from masters are ordered, responsible, \& assiduous in doing duties \&in responsibilities.

\section{Result6}

\begin{tabular}{|c|c|}
\hline Variables & Components \\
\hline (1) & $\begin{array}{l}\text { 1. The first criterion: } 52 / 94 \% \text { of scientific dimensions }-29 / 41 \\
\% \text { of moral behavior }-17 / 64 \% \text { of Educational dimensions ; The } \\
\text { second measure: } 53 / 33 \% \text { of scientific dimensions - } 20 \% \text { of } \\
\text { Research dimensions }-13 / 33 \% \text { of Educational dimensions - } \\
13 / 33 \% \text { of moral behavior ; And third criteria: } 53 / 33 \% \text { of } \\
\text { moral behavior - } 46 / 66 \% \text { of Educational dimensions }-13 / 33 \% \\
\text { of Research dimensions. } \\
2 \text {. The first criterion: } 37 / 03 \% \text { of moral behavior - } 33 / 3 \% \text { of } \\
\text { scientific dimensions - } 29 / 62 \% \text { knowledg - educational } \\
\text { dimensions - } 29 / 62 \% \text {; The second measure: } 40 / 74 \% \text { of moral } \\
\text { behavior - } 29 / 62 \% \text { of scientific dimensions }-29 / 62 \% \text { of } \\
\text { knowledg - educational dimensions; And third criteria: } 48 / 14 \% \\
\text { of knowledg - educational dimensions - } 44 / 44 \% \text { of of moral } \\
\text { behavior - and } 7 / 4 \% \text { of scientific dimensions. }\end{array}$ \\
\hline (1) & $\begin{array}{l}\text { 3. The first criterion: } 53 / 84 \% \text { of scientific dimensions - } 38 / 46 \% \\
\text { of Educational dimensions - } 7 / 69 \% \text { of Research dimensions; } \\
\text { The second measure: } 57 / 69 \% \text { of knowledge - educational - } \\
26 / 92 \% \text { of scientific - reserch dimensions and } 15 / 38 \% \text { of moral } \\
\text { behavior; And third criteria:50 \% of knowledge - educational } \\
\text { dimensions - } 35 \% \text { of scientific dimensions - } 15 \% \text { of moral } \\
\text { behavior. } \\
4 \text {. The first criterion: } 37 / 03 \% \text { of scientific dimensions - } 29 / 62 \% \\
\text { of Educational dimensions - } 22 / 22 \% \text {; of moral behavior - } \\
11 / 11 \% \text { of Research dimensions ; The second measure: } 30 / 76 \% \\
\text { of scientific dimensions - } 30 / 76 \% \text { of moral behavior - } 19 / 23 \% \\
\text { of Research dimensions - } 19 / 23 \% \text { of Educational dimensions; } \\
\text { And third criteria: } 45 / 45 \% \text { of Educational - scientific } \\
\text { dimensions - } 31 / 82 \% \text { of moral behavior- and } 22 / 72 \% \text { of } \\
\text { Research dimensions. } \\
5 \text {. The first criterion: } 48 / 14 \% \text { of scientific - education } \\
\text { dimensions - } 44 / 44 \% \text { of moral behavior - and } 7 / 4 \% \text { of } \\
\text { Research dimensions; the second measure: } 41 / 66 \% \text { of } \\
\text { education dimensions - } 29 / 16 \% \text { of of moral behavior - } 25 \% \text { of } \\
\text { scientific dimensions- and } 4 / 16 \% \% \text { of Research dimensions; } \\
\text { And third criteria: } 40 \% \text { of moral behavior - } 35 \% \text { of knowledg - } \\
\text { educational dimensions - and } 25 \% \text { of Research - scientific } \\
\text { dimensions. }\end{array}$ \\
\hline $\begin{array}{l}\text { 6.Prioritize based on the degree and location of education and } \\
\text { place of employment }\end{array}$ & $\begin{array}{l}\text { 6. The first criterion: } 57 / 69 \% \text { of field of study }-38 / 46 \% \text { of } \\
\text { education place and } 3 / 84 \text { of Place of employment; the second } \\
\text { measure: } \% 50 \text { of Place of employment }-27 / 27 \% \text { of education } \\
\text { place and } 22 / 72 \% \text { of field of study; And third criteria: } 45 / 45 \% \\
\text { of Place of employment - } 31 / 81 \% \text { of education place; and } \\
22 / 72 \% \text { of field of study. }\end{array}$ \\
\hline 7. Important criteria for the Master & $\begin{array}{l}\text { 7. The first criterion: } 86 / 95 \% \text { of dimensions cover }- \text { and } \\
13 / 04 \% \text { of moral behavior ; the second measure: } 76 / 19 \% \text { of } \\
\text { dimensions cover - and } 23 / 8 \% \text { of moral behavior ; And third } \\
\text { criteria: } 64 / 28 \% \text { of dimensions cover }-35 / 71 \% \text { of moral } \\
\text { behavior }\end{array}$ \\
\hline $\begin{array}{l}\text { 8. Measures to meet the expectations of superiors and } \\
\text { colleagues and students and the scientific community }\end{array}$ & $\begin{array}{l}\text { 8. The first criterion: } 41 / 17 \% \text { of scientific dimensions - } \\
29 / 41 \% \text { of moral behavior }-11 / 76 \% \text { of of Research dimensions } \\
\text { and } 11 / 76 \% \text { of Educational dimensions }\end{array}$ \\
\hline
\end{tabular}

Students of the Faculty of Science

Masters teaching quality meter from aspect of down to up (sciences collegians)

Result 7- 38.4 percent are adaptation from didactic masters with are array lesson plan , and also 45.2 percent from masters ability of mean conduction to learners ,\&also 41.2 percent from masters are use didactic aims for collegians ,and 49.2 percent from masters are use evaluation \&didactic new methods, and also 52 percent from masters are use of variety didactic methods and didactic facilities in facilities confine and applicative with kind of lesson and also 38.6 percent from masters are familiar with professional and scientific news , and also 38.6 percent from masters are use of class time for didactic activities, and also 37.2 percent from collegians 
is communion by masters in class activities ,and also 52 percent from masters explanation are clear \& intelligible for collegians.

Result 8 - 36 percent from masters are observe vocation morality \& Islamic methods , and 57.2 percent from masters are transmissible ,and also 41.12 percent masters are adaptation relationship establishment ability with collegian in didactic environment s , and also 42.6 percent from masters are doing his duties in guidance context \& scientific council, and also 34.6 percent from masters are ordered, responsible, \& assiduous in doing duties \&in responsibilities

Result 9:

\begin{tabular}{|c|c|}
\hline Variables & Components \\
\hline 2. Prioritization criteria professors & $\begin{array}{l}\text { 1. The first criterion: } 60 \% \text { of scientific dimensions - } 40 \% \text { of } \\
\text { Educational dimensions; The second measure: } 80 \% \text { of } \\
\text { Educational dimensions - } 20 \% \text { of moral behavior; And third } \\
\text { criteria: only knowledg dimensions. } \\
2 \text {. The first criterion: } 50 \% \text { of scientific dimensions } 28 / 57 \% \text { of } \\
\text { Educational dimensions - } 14 / 28 \% \text { Research dimensions; The } \\
\text { second measure: } 64 / 28 \% \text { of moral behavior - } 35 / 71 \% \text { of } \\
\text { educational - scientific dimensions; And third criteria: } 60 \% \text { of } \\
\text { of moral behavior - and } 40 \% \text { of of recerch - Educational } \\
\text { dimensions. }\end{array}$ \\
\hline 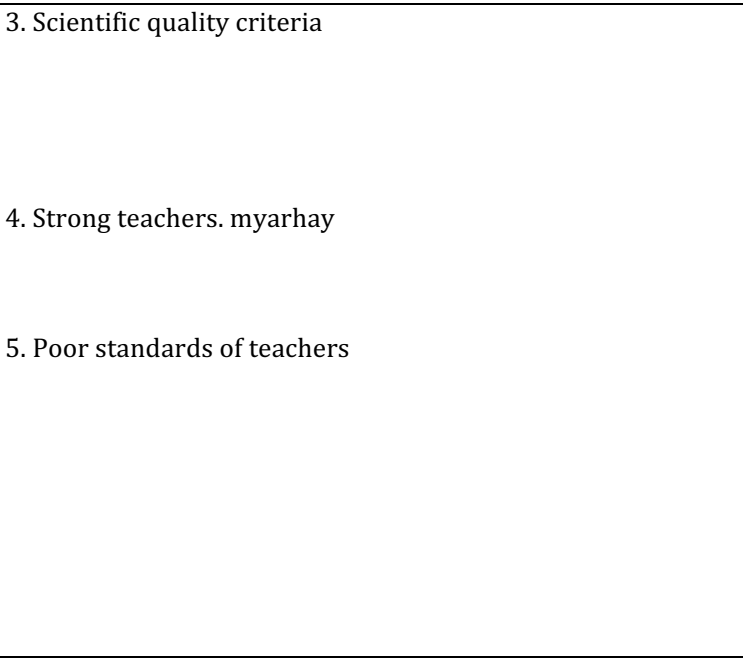 & $\begin{array}{l}\text { 3. The first criterion: } 35 / 71 \% \text { of scientific dimensions }-28 / 57 \% \\
\text { of knowledg - educational dimensions - } 21 / 42 \% \text { of Research } \\
\text { dimensions - and } 14 / 28 \% \text { of moral behavior; The second } \\
\text { measure: } 50 \% \text { of educational dimensions }-35 / 71 \% \text { of scientific } \\
\text { dimensions - } 7 / 14 \% \text { of moral behavior; and } 7 / 14 \% \text { of Research } \\
\text { dimensions; And third criteria: } 50 \% \text { of moral behavior - } 50 \% \text { of } \\
\text { scientific dimensions. } \\
4 \text {. The first criterion: } 42 / 85 \% \text { of scientific dimensions - } 28 / 57 \% \\
\text { of Experimental dimensions - } 14 / 28 \% \text { of Dimensions relations } \\
\text { with foreign teachers - } 14 / 28 \% \text { of Research dimensions ; The } \\
\text { second measure: } 42 / 85 \% \text { of of Research dimensions }-28 / 57 \% \\
\text { of Educational dimensions - } 14 / 28 \% \text { of The dimensions of the } \\
\text { relationship between teacher - student - } 14 / 28 \% \text { of } \\
\text { Relationship with Executives ; And third criteria: } 45 / 45 \% \text { of } \\
\text { Educational - scientific dimensions - } 31 / 82 \% \text { of moral } \\
\text { behavior- and } 22 / 72 \% \text { of Research dimensions. } \\
5 . \text { The first criterion: } 50 \% \text { of } \% \text { of moral behavior - } 33 / 33 \% \text { of } \\
\text { scientific dimensions - and } 16 / 66 \% \text { of education dimensions; } \\
\text { The second measure: } 75 \% \text { of scientific dimensions - } 25 \% \text { of of } \\
\text { moral behavior; And third criteria: only moral behavior. }\end{array}$ \\
\hline $\begin{array}{l}\text { 6.Prioritize based on the degree and location of education and } \\
\text { place of employment }\end{array}$ & $\begin{array}{l}\text { 6. The first criterion: } 61 / 53 \% \text { of education place }-38 / 46 \% \text { of } \\
\text { field of study; the second measure: } 53 / 84 \% \text { of field of study - } \\
30 / 76 \% \text { of education place and } 15 / 38 \% \text { of Place of } \\
\text { employment; And third criteria: } 84 / 61 \% \text { of Place of } \\
\text { employment - } 7 / 69 \% \text { of education place; and } 7 / 69 \% \text { of field of } \\
\text { study. }\end{array}$ \\
\hline 7. Important criteria for the Master & $\begin{array}{l}\text { 7. The first criterion: } 72 / 72 \% \text { of dimensions cover - and } \\
18 / 18 \% \text { of moral behavior - and } 9 / 09 \% \text { Relations between } \\
\text { teachers and students; the second measure: } 66 / 66 \% \text { of } \\
\text { dimensions cover - and } 33 / 33 \% \text { of moral behavior ; And third } \\
\text { criteria: only of dimensions cover. }\end{array}$ \\
\hline $\begin{array}{l}\text { 8. Measures to meet the expectations of superiors and } \\
\text { colleagues and students and the scientific community }\end{array}$ & $\begin{array}{l}\text { 8. } 66 / 66 \text { of scientific and Educational dimensions }-33 / 33 \% \text { of } \\
\text { Research dimensions. }\end{array}$ \\
\hline
\end{tabular}

\section{Self-evaluation Faculty of Humanities}

Masters teaching quality measure with regard from inside (litterae university masters):

Result 10 - 38.6 percent from of teaching topics masters have organization in cast of plan and lessen program specific , and also 40 percent from masters are specify lessen didactic aims for masters .and also 36 percent in context of definite diction and lessen text perfect explanation, they are know herself successful and also 34.6 percent from masters of class time are use for didactic activities, and also 37.2 percent from masters common students in class activity, and also 38.6 percent from masters their explanation for students are clear \& intelligible ,also $44 \%$ from varietal didactic methods \& didactic assist utensil are use in range of facilities and applicative with kind of lessens, and , also 38.6 percent from masters adverts 
in contour of exam questions and or students evaluation kind choice and didactic content \& before periods questions analyzation.

Result 11- 32 percent of masters are diligent in scientific information avocation, and also 48 percent from masters knows his self-researcher.

Result 12- 38.6 percent are successful in relationship with students and also 38.6 percent from masters are successful in relation with coworkers ,and also 42.6 percent of masters are censure able ,and also 29.2 percent of masters are loadable in organization duties doing .

\section{Result 13-}

\begin{tabular}{|c|c|}
\hline Variables & Components \\
\hline 2. Prioritization criteria professors & $\begin{array}{l}\text { 1. The first criterion: } 87 / 5 \% \text { of scientific - Educational } \\
\text { dimensions - } 12 / 5 \% \text { of moral behavior; The second measure: } \\
50 \% \text { of Research dimensions - } 37 / 5 \% \text { of moral behavior - and } \\
12 / 5 \% \text { of Educational dimensions; And third criteria: } 42 / 85 \% \text { of } \\
\text { scientific - Educational dimensions; } 28 / 57 \text { of moral behavior- } \\
\text { and } 28 / 57 \text { Relations between teachers and students. } \\
2 . \text { The first criterion: } 50 \% \text { of moral behavior - } 25 \% \text { of } \\
\text { Educational dimensions - } 12 / 5 \% \text { knowledg dimensions - and } \\
12 / 5 \% \text { Relations between teachers and students; The second } \\
\text { measure: } 37 / 5 \% \text { of Educational dimensions - } 25 \% \text { of scientific } \\
\text { dimensions - } 25 \% \text { of Research dimensions - and } 12 / 5 \% \text { of } \\
\text { moral behavior; And third criteria: } 62 / 5 \% \text { of scientific } \\
\text { dimensions } 25 \% \text { of moral behavior - and } 12 / 5 \% \text { of recerch } \\
\text { dimensions. }\end{array}$ \\
\hline $\begin{array}{l}\text { 4. Strong teachers. myarhay } \\
\text { 5. Poor standards of teachers }\end{array}$ & $\begin{array}{l}\text { 3. The first criterion: } 62 / 5 \% \text { of scientific dimensions }-25 \% \text { of } \\
\text { Research dimensions - } 12 / 5 \% \text { of Research dimensions; The } \\
\text { second measure: } 50 \% \text { of scientific dimensions - } 37 / 5 \% \text { of } \\
\text { Educational dimensions }-12 / 5 \% \text { of Research dimensions; and } \\
7 / 14 \% \text { of Research dimensions; And third criteria: } 50 \% \text { of } \\
\text { moral behavior - } 50 \% \text { of Research dimensions. } \\
4 \text {. The first criterion: } 42 / 85 \% \text { of Professional Dimensions - } \\
28 / 57 \% \text { of Research dimensions - } 14 / 28 \% \text { of moral behavior } \\
\text { with foreign teachers - } 14 / 28 \% \text { of Educational dimensions; The } \\
\text { second measure: } 57 / 14 \% \text { of Educational dimensions - } 28 / 57 \% \\
\text { of scientific dimensions - } 14 / 28 \% \text { of Research dimensions ; } \\
\text { And third criteria: } 57 / 14 \% \text { of Educational - scientific } \\
\text { dimensions - } 42 / 85 \% \text { of Research dimensions. } \\
5 \text {. The first criterion: } 33 / 33 \% \text { of } \% \text { of moral behavior - } 42 / 85 \% \\
\text { of scientific dimensions - and } 33 / 33 \% \text { of knowledg dimensions; } \\
\text { The second measure: } 88 / 89 \% \text { of scientific - Educational } \\
\text { dimensions - } 11 / 11 \% \text { of of moral behavior; And third criteria: } \\
42 / 85 \% \text { Relations between teachers and students - } 28 / 75 \% \text { of } \\
\text { Educational dimensions - } 14 / 28 \% \text { of scientific - Educational- } \\
\text { and } 14 / 28 \% \text { moral behavior. }\end{array}$ \\
\hline $\begin{array}{l}\text { 6.Prioritize based on the degree and location of education and } \\
\text { place of employment }\end{array}$ & $\begin{array}{l}\text { 6. The first criterion: } 57 / 14 \% \text { of field of study }-38 / 46 \% \text { of } \\
\text { education place; the second measure: } 66 / 66 \% \text { of field of study - } \\
16 / 66 \% \text { of education place and } 16 / 66 \% \text { of Place of employment; } \\
\text { And third criteria: } 50 \% \text { of Place of employment }-50 \% \text { of } \\
\text { education place. }\end{array}$ \\
\hline 7. Important criteria for the Master & $\begin{array}{l}\text { 7. The first criterion: } 88 / 89 \% \text { of dimensions cover }- \text { and } \\
11 / 11 \% \text { of moral behavior; the second measure: } 66 / 66 \% \text { of } \\
\text { moral behavior - and } 33 / 33 \% \text { of moral behavior; And third } \\
\text { criteria: } 83 / 33 \% \text { of moral behavior - and } 16 / 66 \% \text { of dimensions } \\
\text { cover. }\end{array}$ \\
\hline $\begin{array}{l}\text { 8. Measures to meet the expectations of superiors and colleagues } \\
\text { and students and the scientific community }\end{array}$ & $\begin{array}{l}\text { 8. } 46 / 15 \text { of moral behavior }-30 / 76 \% \text { of scientific dimensions - } \\
7 / 69 \% \text { of knowledge dimensions }-7 / 69 \% \text { of Educational } \\
\text { dimensions - and } 7 / 69 \% \text { of Research dimensions. }\end{array}$ \\
\hline
\end{tabular}

Self-evaluation of Mathematical Sciences

Masters teaching quality level with look from inward

Result 14- 38.6 percent from masters have organization in plan and lesson program , and also 32.2 percent of masters are specify lesson didactic aims for students ,and also 36 percent of masters are successful in context of clear diction and lesson text perfect . and as well as , 36.2 percent of masters use class time for didactic activity and eke , 41.4percent from masters 
make common students in class activity ,and too, 37.2 percent of explanation 's masters are clear and understandable for student .and also ,44percent of masters use from variety didactic methods and didactic help utensil in facilities range and applicative with kind of lesson, too , 37.2 percent of masters are attending in exam questions design \& or students examination kind choice to aims \& didactic content \& before circuits analysis .

Result 15- 34.6 percent of masters are diligent in scientific information vocation, also 40 percent of masters are researcher.

Result 16 - 29.2 percent of masters are successful in adaptation relation with students, and too, 40 percent of masters are successful with coworkers , and eke , 38.6 percent of maters are criticism able, and also , 28 percent of masers are responsible able in organization duties doing.

\section{Result 17-}

\begin{tabular}{|c|c|}
\hline Variables & Components \\
\hline 1. Prioritization criteria groups & $\begin{array}{l}\text { 1. The first criterion: } 53.33 \% \text { of Educational dimensions - } \\
33.33 \% \text { of Research dimensions - } 8.33 \% \text { of knowledg } \\
\text { dimensions; The second measure: } 50 \% \text { of Educational } \\
\text { dimensions }-33.3 \% \text { of Research dimensions - and } 16.66 \% \text { of } \\
\text { scientific dimensions; And third criteria: } 50 \% \text { of Research } \\
\text { dimensions; } 25 \% \text { of Educational dimensions - } 12.5 \% \text { Relations } \\
\text { between teachers and students- and } 12.5 \% \text { of Cultural } \\
\text { Dimensions } \\
2 \text {. The first criterion: } 50 \% \text { of Research dimensions - } 33.33 \% \text { of } \\
\text { Educational dimensions - } 16.66 \% \text { moral behavior; The second } \\
\text { measure: } 50 \% \text { of Educational dimensions - } 25 \% \text { of scientific } \\
\text { dimensions - } 25 \% \text { Relations between teachers and students; } \\
\text { And third criteria: } 44.44 \% \text { of Educational- scientific } \\
\text { dimensions-and } 44.44 \% \text { of moral behavior - } 11.11 \% \text { of } \\
\text { Research dimensions }\end{array}$ \\
\hline 3. Scientific quality criteria & $\begin{array}{l}\text { 3. The first criterion: } 69.23 \% \text { of Research dimensions - } 30.76 \% \\
\text { of scientific dimensions; The second measure: } 61.53 \% \text { of } \\
\text { Educational dimensions - } 15.38 \% \text { of moral behavior - } 15.38 \% \\
\text { of Research dimensions; and } 7.69 \% \text { of science dimensions; And } \\
\text { third criteria: } 42.58 \% \text { of moral behavior - } 28.75 \% \text { of Relations } \\
\text { between teachers and students - } 14.28 \% \text { of Research } \\
\text { dimensions - } 14.28 \% \text { of science dimensions. } \\
4 \text {. The first criterion: } 45.45 \% \text { of Research dimensions - } \\
27.27 \% \text { of Educational dimensions - } 27.27 \% \text { of science } \\
\text { dimension ; The second measure: } 44.44 \% \text { of Educational } \\
\text { dimensions - } 22.22 \% \text { of moral behavior - } 11.11 \% \text { of science } \\
\text { dimension ; And third criteria:50\% of Research dimensions - } \\
33.33 \% \text { of science dimension - and } 16.66 \% \text { Relations between } \\
\text { teachers and students. } \\
5 \text { The first criterion: } 55.55 \% \text { of Relations between teachers } \\
\text { and students and Colleague - } 22.22 \% \text { of scientific dimensions - } \\
\text { and } 22.22 \% \text { of Financial; The second measure: } 25 \% \text { of } \\
\text { Educational dimensions - } 25 \% \text { of of moral behavior - } 25 \% \text { of } \\
\text { Facilities dimensions - and } 25 \% \text { of Assessment dimensions; } \\
\text { And third criteria: } 33.33 \% \text { of Relations between teachers and } \\
\text { students and world }-33.33 \% \text { of Research dimensions - } \\
16.66 \% \text { of Educational dimensions - and } 16.66 \% \text { of educational } \\
\text { facilities dimensions }\end{array}$ \\
\hline $\begin{array}{l}\text { 6.Prioritize based on the degree and location of education and } \\
\text { place of employment }\end{array}$ & $\begin{array}{l}\text { 6. The first criterion: } 45.45 \% \text { of education place }-36.36 \% \text { of } \\
\text { Place of employment }-18.18 \% \text { of field of study; the second } \\
\text { measure: } \% 50 \text { of field of study - } 33.33 \% \text { of education place and } \\
16.66 \% \text { of Place of employment; And third criteria: } 50 \% \text { of } \\
\text { Place of employment }-33.33 \% \text { of of field of study - and } 16.66 \$ \\
\text { of education place. }\end{array}$ \\
\hline 7. Important criteria for the Master & $\begin{array}{l}\text { 7. The first criterion: only dimensions cover; the second } \\
\text { measure: } 75 \% \text { of dimensions cover - and } 25 \% \text { of moral } \\
\text { behavior; And third criteria: } 62.5 \% \text { of dimensions cover - and } \\
37.5 \% \text { of moral behavior. }\end{array}$ \\
\hline $\begin{array}{l}\text { 8. Measures to meet the expectations of superiors and } \\
\text { colleagues and students and the scientific community }\end{array}$ & $\begin{array}{l}\text { 8. } 50 \text { of moral behavior }-50 \% \text { of Research - scientific } \\
\text { dimensions. }\end{array}$ \\
\hline
\end{tabular}


Didactic quality in idea of masters masters teaching quality level with look of inward

Result 18 - 42 percent his teaching topic masters have organization in one plane \& distinctive lesson program , and also 32 percent of masters specify lesson didactic aims for students .and too , 32 percent masters make common students in class activity ,and as well as , 40 percent of masters are successful in context of clear diction and lesson text perfect explanation , \& eke36 percent of explanation 's masters are clear and understand able for students ., too, 32 percent of masters are use class time for didactic activity. Also 36 percent of masters are use variety didactic methods in facilities range and applicative with kind of lesson and as well as, 32 percent of masters are attending in exam question plan \& or students examination kind choice about aims \& didactic content and before periods question analysis.

Result 19- 40 percent of masters are diligent in scientific information vocation, also 32 percent of masters are researcher.

Result 20- 48 percent of masters are successful in adaptation relation with students, and Also Also 56 percent of masters are successful in adaption relation with coworkers. And too 44 percent of masters are criticism able, and eke 32 percent of masters are responsible able in organization duties doing.

\section{Result 21-}

\begin{tabular}{|c|c|}
\hline Variables & Components \\
\hline 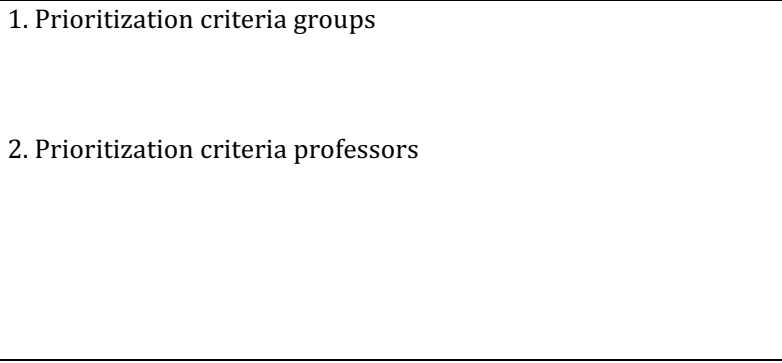 & $\begin{array}{l}\text { 1. The first criterion: } 50 \% \text { of profetional dimensions }-25 \% \text { of } \\
\text { scientific dimensions - } 25 \% \text { of moral behavior; The second } \\
\text { measure: } 50 \% \text { of knowledg dimensions }-25 \% \text { of moral behavior } \\
\text { - and } 25 \% \text { of scientific dimensions; And third criteria: } 50 \% \text { of } \\
\text { moral behavior; } 50 \% \text { of Educational dimensions. } \\
2 \text {. The first criterion: } 40 \% \text { of scientific dimensions - } 20 \% \text { of } \\
\text { Educational dimensions - } 20 \% \text { of Training dimensions - and } \\
20 \% \text { of profetional dimensions; The second measure: } 40 \% \text { of } \\
\text { Training dimensions - } 40 \% \text { of moral behavior - } 20 \% \text { Research } \\
\text { dimensions; And third criteria: } 80 \% \text { of moral behavior - } 20 \% \text { of } \\
\text { knowledg dimensions }\end{array}$ \\
\hline $\begin{array}{l}\text { 4. Strong teachers. myarhay } \\
\text { 5. Poor standards of teachers }\end{array}$ & $\begin{array}{l}\text { 3. The first criterion: } 40 \% \text { of Research dimensions - } 40 \% \text { of } \\
\text { Training dimensions - } 20 \% \text { of moral behavior; The second } \\
\text { measure: } 40 \% \text { of Training dimensions - } 40 \% \text { of science } \\
\text { dimension - } 20 \% \text { of Research dimensions; And third criteria: } \\
60 \% \text { of Training dimensions - } 40 \% \text { of Research dimensions. } \\
4 \text {. The first criterion: } 40 \% \text { of Research dimensions - } 40 \% \text { of } \\
\text { science dimension - and } 20 \% \text { of Training dimensions ; The } \\
\text { second measure: } 40 \% \text { of moral behavior- } 40 \% \text { Relations } \\
\text { between teachers and students - } 20 \% \text { of Research dimensions; } \\
\text { And third criteria: } 40 \% \text { of science dimension } 40 \% \text { of Relations } \\
\text { between professor with colleagues and public and private } \\
\text { government - and } 20 \% \text { of Research dimensions } \\
5 . \text { The first criterion: } 40 \% \text { of science dimension - } 40 \% \text { of } \\
\text { Research dimensions - and } 20 \% \text { of moral behavior; The second } \\
\text { measure: } 80 \% \text { of moral behavior - } 20 \% \text { of Research } \\
\text { dimensions ; And third criteria: } 60 \% \text { of moral behavior }-40 \% \\
\text { science dimension }\end{array}$ \\
\hline $\begin{array}{l}\text { 6.Prioritize based on the degree and location of education and } \\
\text { place of employment }\end{array}$ & $\begin{array}{l}\text { 6. The first criterion: } 66.66 \% \text { of Place of employment }-33.33 \% \\
\text { of education place; The second measure: } \% 33 / 33 \text { of field of } \\
\text { study }-33.33 \% \text { of education place and } 33.33 \% \text { of Place of } \\
\text { employment; And third criteria: } 66.66 \% \text { of field of study - and } \\
33.33 \% \text { of education place. }\end{array}$ \\
\hline 7. Important criteria for the Master & $\begin{array}{l}\text { 7. The first criterion: } 50 \% \text { of dimensions cover and } 50 \% \text { of } \\
\text { moral behavior; The second measure: } 50 \% \text { of dimensions cover } \\
\text { - and } 50 \% \text { of moral behavior; And third criteria: only } \\
\text { dimensions cover. }\end{array}$ \\
\hline $\begin{array}{l}\text { 8. Measures to meet the expectations of superiors and colleagues } \\
\text { and students and the scientific community }\end{array}$ & $\begin{array}{l}\text { 8. } 50 \% \text { of moral behavior }-25 \% \text { of Research - scientific } \\
\text { dimensions - and } 25 \% \text { of Relations between teachers and } \\
\text { students. }\end{array}$ \\
\hline
\end{tabular}


Result 22 - 50 percent of masters are exception able mentality and also 48 percent of masters are adaptation relation with his self-coworkers \& too 52 percent of masters are adaptation relation with his self-students, eke 44 percent of masters have cooperation in didactic activity with member of group. Also, 46 percent of masters make observe professional morality \& Islamic whimper.

Result 23 - 48 percent of masters have cooperation in array lesson units admission in group , also ,52 percent of masters overlap his self-didactic abilities and research about another coworkers \& too , 52 percent of masters have overlap against percept and communion in make tunicated in research \& didactic activities of another coworkers .

Result 24 -44 percent of masters are in enthusiast scientific information innovation, and also 60 percent of masters or member of group have cooperation in research activity.

Result 25 - didactic quality of masters coworkers look

\begin{tabular}{|c|c|}
\hline Variables & Components \\
\hline 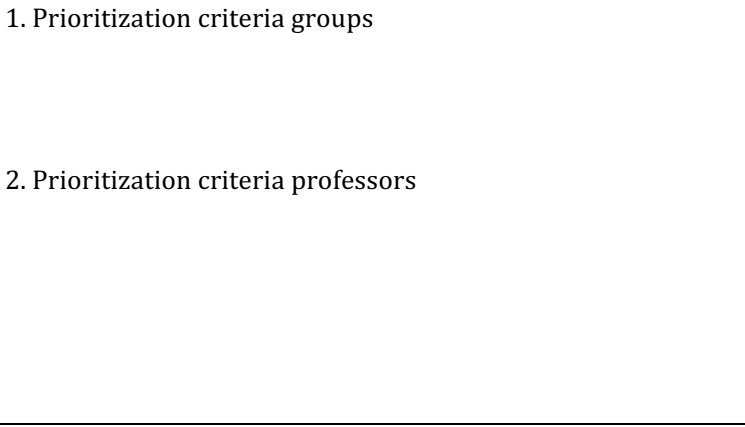 & $\begin{array}{l}\text { 1. The first criterion: } 87.5 \% \text { of Training - scientific dimensions } \\
-12.5 \% \text { of moral behavior; The second measure: } 50 \% \text { of } \\
\text { Research dimensions }-37.5 \% \text { of moral behavior - and } 12.5 \% \text { of } \\
\text { Training - scientific dimensions; And third criteria: } 42.85 \% \text { of } \\
\text { Training - scientific dimensions; } 28.57 \% \text { of moral behavior- } \\
\text { and } 28.57 \% \text { of Relations between teachers and students. } \\
2 \text {. The first criterion: } 50 \% \text { of moral behavior - } 25 \% \text { of Training } \\
\text { dimensions - } 12.5 \% \text { of knowledg dimensions - and } 12.5 \% \text { of } \\
\text { Relations between teachers and students; The second measure: } \\
37.5 \% \text { of Training dimensions - } 25 \% \text { of scientific dimensions } \\
-25 \% \text { Research dimensions - and } 12.5 \% \text { of moral behavior; } \\
\text { And third criteria: } 62.5 \% \text { of of scientific dimensions - } 25 \% \text { of } \\
\text { moral behavior - and } 12.5 \% \text { Research dimensions. }\end{array}$ \\
\hline 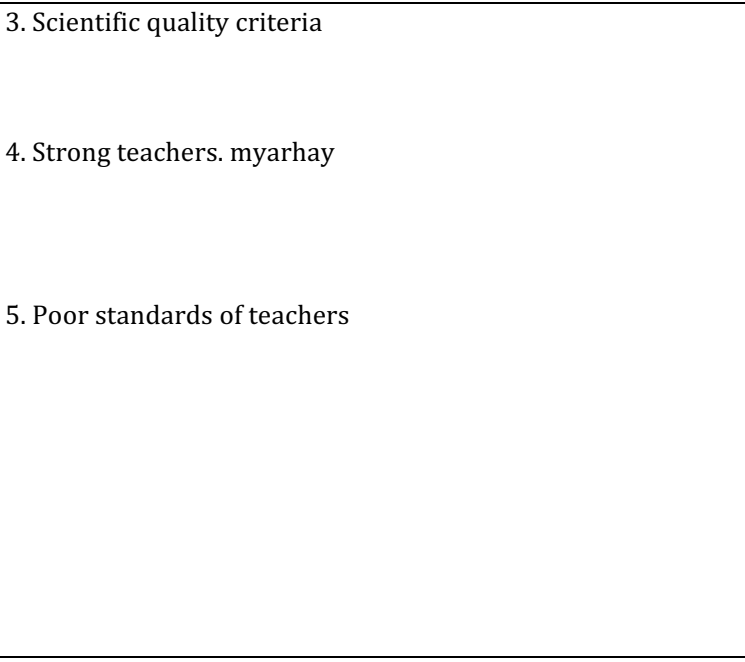 & $\begin{array}{l}\text { 3. The first criterion: } 62.5 \% \text { of scientific dimensions - } 25 \% \text { of } \\
\text { Research dimensions - } 12.5 \% \text { of moral behavior; The second } \\
\text { measure: } 50 \% \text { of science dimension - } 37.5 \% \text { of Training } \\
\text { dimensions - and } 12.5 \% \text { Research dimensions; And third } \\
\text { criteria: } 50 \% \text { of moral behavior - } 50 \% \text { of Research } \\
\text { dimensions. } \\
4 \text {. The first criterion: } 42.85 \% \text { of profetional dimensions - } \\
28.57 \% \text { of Research dimensions - } 14.28 \% \text { of moral behavior } \\
\text { - and } 14.28 \% \text { of Training dimensions ; The second measure: } \\
57.14 \% \text { of Training dimensions - } 28.57 \% \text { of scientific } \\
\text { dimensions - } 14.28 \% \text { of Research dimensions; And third } \\
\text { criteria: } 57.14 \% \text { of Training - science dimension - } 42.85 \% \text { of } \\
\text { Research dimensions } \\
5 \text {. The first criterion: } 33.33 \% \text { of science dimension }-40 \% \text { of } \\
\text { knowledg dimension - and } 33.33 \% \text { of moral behavior; The } \\
\text { second measure: } 88.89 \% \text { of Training - science dimensions - } \\
11.11 \% \text { of moral behavior; And third criteria: } 42.85 \% \text { of } \\
\text { Relations between teachers and students- } 28.75 \% \text { of } \\
\text { Educational dimensions - } 14.28 \% \text { of science dimensions - } \\
14.28 \% \text { of moral behavior. }\end{array}$ \\
\hline $\begin{array}{l}\text { 6.Prioritize based on the degree and location of education and } \\
\text { place of employment }\end{array}$ & $\begin{array}{l}\text { 6. The first criterion: } 57.14 \% \text { of of field of study }-42.85 \% \text { of } \\
\text { education place; The second measure:\% } 66.66 \text { of field of study } \\
-16.66 \% \text { of education place and } 16.66 \% \text { of Place employment; } \\
\text { And third criteria: } 50 \% \text { of of Place employment - and } 50 \% \text { of } \\
\text { education place. }\end{array}$ \\
\hline 7. Important criteria for the Master & $\begin{array}{l}\text { 7. The first criterion: } 88.89 \% \text { of dimensions cover and } 11.11 \% \\
\text { of moral behavior; The second measure: } 66.66 \% \text { of dimensions } \\
\text { cover - and } 33.33 \% \text { of moral behavior; And third criteria: } \\
83.33 \% \text { of moral behavior - and } 16.66 \% \text { of dimensions cover. }\end{array}$ \\
\hline $\begin{array}{l}\text { 8. Measures to meet the expectations of superiors and } \\
\text { colleagues and students and the scientific community }\end{array}$ & $\begin{array}{l}\text { 8. } 46.15 \% \text { of moral behavior }-30.76 \% \text { of scientific dimensions } \\
-7.69 \% \text { of knowledg dimension }-7.69 \% \text { of Training } \\
\text { dimensions - and } 7.69 \% \text { of Research dimensions }\end{array}$ \\
\hline
\end{tabular}

Coworkers of School of Mathematical Sciences

Masters teaching quality level with look of side (science collegiate masters coworkers)

Result 26 - 61.4 percent of masters have exceptionable mentality and also 47 percent of masters have adaptation relation with his coworkers, too, 51.4 percent of masters have 
adaptation relation with his students and eke 44.2 percent of masters are observe professional morality .

Result 27-47 percent have observe in array lesson units admission , and also 57 percent of masters are intersection his didactic abilities \& research with another their coworkers,$\&$ too 58.4 percent of masters have reciprocate perception and communion in covering didactic activity and research \& eke 51.4 percent of masters have cooperation in didactic activity with member of group.

Result 28 - 51.4 percent are interested in innovation \& new scientific information, also, 57 percent of masters have cooperation in research activity with member of group.

Result 29- didactic quality in idea of masters coworkers

\begin{tabular}{|c|c|}
\hline Variables & Components \\
\hline 2. Prioritization criteria professors & $\begin{array}{l}\text { 1. The first criterion: } 53.33 \% \text { of Training - scientific } \\
\text { dimensions - } 33.33 \% \text { of Research dimensions - and } 8.33 \% \text { of } \\
\text { knowledg dimensions; The second measure: } 50 \% \text { of Training } \\
\text { dimensions }-33.33 \% \text { of Research dimensions - and } 16.66 \% \text { of } \\
\text { scientific dimensions; And third criteria: } 50 \% \text { of Research } \\
\text { dimensions; } 25 \% \text { of Training dimensions - and } 12.5 \% \text { of } \\
\text { Relations between teachers and students }-12.35 \% \text { of cultural } \\
\text { dimensions. } \\
2 \text { The first criterion: } 50 \% \text { of Research dimensions - } 33.33 \% \text { of } \\
\text { Training dimensions - } 16.66 \% \text { of moral behavior; The second } \\
\text { measure: } 50 \% \text { of Training dimensions - } 25 \% \text { of scientific } \\
\text { dimensions - } 25 \% \text { Research dimensions - and } 12.5 \% \text { of } \\
\text { Relations between teachers and students; And third criteria: } \\
44.44 \% \text { of Training - scientific dimensions - } 44.44 \% \text { of moral } \\
\text { behavior - and } 11.11 \% \text { Research dimensions. }\end{array}$ \\
\hline 3. Scientific quality criteria & $\begin{array}{l}\text { 3. The first criterion: } 69.23 \% \text { of Research dimensions - } 30.76 \% \\
\text { of scientific dimensions; The second measure: } 61.53 \% \text { of } \\
\text { Training dimensions } 15.38 \% \text { of moral behavior }-15.38 \% \\
\text { Research dimensions - and } 7.69 \text { of scientific dimensions; And } \\
\text { third criteria: } 42.58 \% \text { of moral behavior - } 28.75 \% \text { of Relations } \\
\text { between teachers and students - } 14.28 \% \text { of Research } \\
\text { dimensions - and } 14.28 \% \text { of scientific dimensions. }\end{array}$ \\
\hline 4. Strong teachers. myarhay & $\begin{array}{l}\text { 4. The first criterion: } 45.45 \% \text { of Research dimensions - } \\
27.27 \% \text { of Training dimensions }-27.27 \% \text { of scientific } \\
\text { dimensions; The second measure: } 44.44 \% \text { of Training } \\
\text { dimensions }-22.22 \% \text { of moral behavior }-22.22 \% \text { of Research } \\
\text { dimensions - and } 11.11 \% \text { of of scientific dimensions ; And } \\
\text { third criteria: } 50 \% \text { of Research dimensions }-33.33 \% \text { of } \\
\text { science dimension - } 16.66 \% \text { of Relations between teachers } \\
\text { and students. }\end{array}$ \\
\hline & $\begin{array}{l}\text { 5. The first criterion: } 55.55 \% \text { of Relations between teachers } \\
\text { and students and cowrker }-22.22 \% \text { of scientific dimensions - } \\
\text { and } 22.22 \% \text { of efencial behavior; The second measure: } 25 \% \text { of } \\
\text { Training dimensions - } 25 \% \text { of moral behavior }-25 \% \text { of } \\
\text { Assessment dimensions - and } 25 \% \text { of Facilities dimensions; } \\
\text { And third criteria: } 33.33 \% \text { of Relations between teachers and } \\
\text { students- } 33.33 \% \text { of Research dimensions - } 16.66 \% \text { of Training } \\
\text { dimensions }-16.66 \% \text { of educational facilities dimensions. }\end{array}$ \\
\hline $\begin{array}{l}\text { 6.Prioritize based on the degree and location of education } \\
\text { and place of employment }\end{array}$ & $\begin{array}{l}\text { 6. The first criterion: } 45.45 \% \text { of education place }-36.36 \% \text { of } \\
\text { Place employment }-18.18 \% \text { of field of study; The second } \\
\text { measure: } \% 50 \text { of education place }-33.33 \% \text { of education place } \\
\text { and } 16.66 \% \text { of Place employment; And third criteria: } 50 \% \text { of } \\
\text { Place employment - } 33.33 \% \text { of field of study - and } 16.66 \% \\
\text { education place. }\end{array}$ \\
\hline 7. Important criteria for the Master & $\begin{array}{l}\text { 7. The first criterion: only cover dimensions; The second } \\
\text { measure: } 75 \% \text { of cover dimensions - and } 25 \% \text { of moral } \\
\text { behavior; And third criteria: } 62.5 \% \text { of dimensions cover- } 37.5 \% \\
\text { of moral behavior. }\end{array}$ \\
\hline $\begin{array}{l}\text { 8. Measures to meet the expectations of superiors and } \\
\text { colleagues and students and the scientific community }\end{array}$ & $\begin{array}{l}\text { 8. } 50 \% \text { of moral behavior }-50 \% \text { of Research - scientific } \\
\text { dimensions. }\end{array}$ \\
\hline
\end{tabular}


Masters teaching quality level with look of side (base science collegiate masters coworkers) Result 30 - 52 percent of masters have exceptionable mentality ,also 52 percent of masters have adaptation relation with his coworkers \& also 52 percent of masters have adaptation relation with his students, also 60 percent of masters are regarding professional morality .

Result 31 - 48 percent of masters have cooperation in array lesson units reception in group, also masters 60 percent have intersection didactic abilities and his research with another coworkers, also 60 percent of masters have cooperation in masters in didactic activities with members of group . Too, 56 percent of masters have against perception in covering didactic activities \& research of another coworkers.

Result 32-68 percent of masters have interested in innovation his self-scientific information, eke, 72 percent of masters have cooperation in research activities with member of group

Result 33- didactic quality of masters coworkers look

\begin{tabular}{|c|c|}
\hline Variables & Components \\
\hline$x^{2}$ & $\begin{array}{l}\text { 1. The first criterion: } 50 \% \text { of profetional dimensions - } 25 \% \text { of } \\
\text { scientific dimensions - and } 25 \% \text { of moral behavior; The second } \\
\text { measure: } 50 \% \text { of knowledg dimensions }-25 \% \text { of moral behavior } \\
\text { - and } 25 \% \text { of scientific dimensions; And third criteria: } \% 50 \text { of } \\
\text { Training dimensions - and } 50 \% \text { of Training dimensions. } \\
2 \text {. The first criterion: } 40 \% \text { of scientific dimensions }-20 \% \text { of } \\
\text { Training dimensions - } 20 \% \text { of Education dimensions - } 20 \% \text { of } \\
\text { profetional dimensions; The second measure: } 40 \% \text { of Training } \\
\text { dimensions - } 40 \% \text { of moral behavior - and } 20 \% \text { of Research } \\
\text { dimensions; And third criteria: } 80 \% \text { of moral behavior - and } \\
20 \% \text { of knowledge dimensions. }\end{array}$ \\
\hline 4. Strong teachers. myarhay & $\begin{array}{l}\text { 3. The first criterion: } 40 \% \text { of Research dimensions - } 40 \% \text { of } \\
\text { Training dimensions - and } 20 \% \text { of moral behavior; The second } \\
\text { measure: } 40 \% \text { of Training dimensions }-40 \% \text { of scientific } \\
\text { dimensions - and } 20 \% \text { of Research dimensions; And third } \\
\text { criteria: } 60 \% \text { of Training dimensions - } 40 \% \text { of Research } \\
\text { dimensions. } \\
4 \text {. The first criterion: } 40 \% \text { of Research dimensions }-40 \% \text { of } \\
\text { scientific dimensions - } 20 \% \text { of Training dimensions; The second } \\
\text { measure: } 40 \% \text { of moral behavior - } 40 \% \text { of Relations between } \\
\text { teachers and students - } 20 \% \text { of Research dimensions - and } \\
11.11 \% \text { of scientific dimensions ; And third criteria: } 40 \% \text { of } \\
\text { science dimension - } 40 \% \text { of The relationship between teacher } \\
\text { with colleagues and public and private bodies - and } 20 \% \text { of } \\
\text { Research dimensions. } \\
5 \text {. The first criterion: } 40 \% \text { of scientific dimensions - } 40 \% \text { of } \\
\text { Research dimensions } 20 \% \text { of moral behavior; The second } \\
\text { measure: } 80 \% \text { of moral behavior - } 20 \% \text { of Research } \\
\text { dimensions; And third criteria: } 60 \% \text { of moral behavior }-40 \% \text { of } \\
\text { scientific dimensions }\end{array}$ \\
\hline $\begin{array}{l}\text { 6.Prioritize based on the degree and location of education and } \\
\text { place of employment }\end{array}$ & $\begin{array}{l}\text { 6. The first criterion: } 66.66 \% \text { of Place employment }-33.33 \% \text { of } \\
\text { education place; The second measure: } 33.33 \% \text { of education place } \\
-33.33 \% \text { of field of study and } 33.33 \% \text { of Place employment; And } \\
\text { third criteria: } 66.66 \% \text { of field of study } 33.33 \% \text { education place. }\end{array}$ \\
\hline 7. Important criteria for the Master & $\begin{array}{l}\text { 7. The first criterion: } 50 \% \text { of cover dimensions - and } 50 \% \text { of } \\
\text { moral behavior; The second measure: } 50 \% \text { of cover dimensions } \\
\text { - and } 50 \% \text { of moral behavior; And third criteria: only } \\
\text { dimensions cover. }\end{array}$ \\
\hline $\begin{array}{l}\text { 8. Measures to meet the expectations of superiors and colleagu } \\
\text { and students and the scientific community }\end{array}$ & $\begin{array}{l}\text { 8. } 50 \% \text { of moral behavior - } 25 \% \text { of Research - scientific } \\
\text { dimensions - and } 25 \% \text { Relations between teachers and students. }\end{array}$ \\
\hline
\end{tabular}

Zanjan university high categories

Masters teaching quality level with look of up to down (humanism sciences collegiate group manager)

Faculty of Humanities

Result 34 - 30 percent of masters have acting tendance and effective in nominative program tray didactic environment, also 30 percent of masters have acting tendance and effective in nominative program tray didactic seminars \& detectives, also 30 percent of masters have 
acting tendance in nominative program tray group meeting and eke 30 percent of masters are array , array duties by group .

Result 35 - 30 percent of masters are interested to partnership in research activities, also 40 percent of masters have familiar with scientific news \& professional.

Result 36 - 40 percent of masters are regarding professional morality, too, 30 percent of masters have adaptation relation establishment abilities with students in didactic environment, also 40 percent of masters have adaptation relation establishment abilities with coworkers, eke , 50 percent of masters are wealthy exceptionable mentality .

Result 37- 50 percent of masters are use didactic new methods and examination a lso 40 percent of masters have scientific meaning conduction abilities to learners , also , 50 percent of masters are exceptionable mentality .also , 40 percent of masters have artifice in applicative didactic ,too , 30 percent of masters are adaptation didactic methods with array lesson plane.

School of Mathematical Sciences

Masters teaching quality level with look from up to down (sciences collegiate groups' manange)

Result 38- they are effective tendance and very good effective in appointed program against didactic environment, they have effective tendancee and high active in workshops \& appointed programs against didactic systems, they are interested to partnership in research activities, they are high familiar with scientific news \& professional .They are use didactic new methods \& examination, they are very good ability in scientific means conduction to learners , and in acting didactic ,have high proficiency and masters have very good adaption array lesson plane, \& they array duties by group.

Result 39 - they are observe professional, adaptation relation establishment very good ability with students in didactic environment, very good relation establishment ability with coworkers, have very good exceptionable mentality.

Masters teaching quality examination result with look of up to down (humanism collegiate, collegiate chief)

Faulty of Humanities

Result 40 - high participate, in collegiate didactic activities, intermediate participate in collegiate research activities, having intermediate cooperation with didactic adjutancy for didactic works acting, good participate in research - didactic activities in university , intermediate participate in research - didactic activities in university.

Result 41 - establishment good relation with coworkers, establishment good relation with students, observe values \& professional, doing his self duties in guidance context \& good scientific, having good exceptionable, observe of collocation, responsible in doing duties \& responsibility.

\section{University Faculty of Humanities}

Masters teaching quality examination result with look from up to down (sciences collegiate, collegiate chief)

Result 42- high participate ,in collegiate didactic activities, very good participate in collegiate research activities, having very good cooperation with didactic adjutancy for didactic works acting, good participate in research - didactic activities in university, good participate in research - didactic activities in university. 
Result 43- establishment of high relation with coworkers, establishment very good relation with students, having very good exceptionable, very good doing in context of guidance \& scientific council , observe of arrangement, responsibility very good assiduity in doing duties $\&$ responsibilities, believer to very good regulation and research $\&$ didactic precept.

Result 44- didactic quality of collegiate chief idea

\begin{tabular}{|c|c|}
\hline Variables & Components \\
\hline 1. Prioritization criteria groups & $\begin{array}{l}\text { 1. The first criterion: only Training dimensions; The second } \\
\text { measure: } 50 \% \text { of Training dimensions - } 50 \% \text { of Research } \\
\text { dimensions; And third criteria: } 50 \% \text { of Research dimensions - } \\
\text { and } 50 \% \text { of Consultation dimensions. }\end{array}$ \\
\hline 2. Prioritization criteria professors & $\begin{array}{l}\text { 2. The first criterion: } 50 \% \text { of moral behavior }-20 \% \text { of } \\
\text { Training dimensions; The second measure: } 50 \% \text { of Research } \\
\text { dimensions }-50 \% \text { of Consultation dimensions; And third } \\
\text { criteria: } 50 \% \text { of moral behavior - and } 50 \% \text { of Training } \\
\text { dimensions. }\end{array}$ \\
\hline $\begin{array}{l}\text { 3. Scientific quality criteria } \\
\text { 4. Strong teachers. myarhay } \\
\text { 5. Poor standards of teachers }\end{array}$ & $\begin{array}{l}\text { 3. The first criterion: } 50 \% \text { of Training dimensions - and } 50 \% \\
\text { of moral behavior; The second measure: } 50 \% \text { of Training } \\
\text { dimensions }-50 \% \text { of Research dimensions; And third } \\
\text { criteria: only duties dimensions. } \\
4 \text {. The first criterion: } 50 \% \text { of Training dimensions - } 50 \% \text { of } \\
\text { Education dimensions; The second measure: only Training } \\
\text { Research dimensions; And third criteria: only Research } \\
\text { dimensions. } \\
5 \text {. The first criterion: } 50 \% \text { of scientific dimensions - } 50 \% \text { of } \\
\text { moral behavior; The second measure: } 50 \% \text { of moral behavior } \\
-50 \% \text { of Training dimensions; And third criteria: only moral } \\
\text { behavior. }\end{array}$ \\
\hline $\begin{array}{l}\text { 6.Prioritize based on the degree and location of education } \\
\text { and place of employment }\end{array}$ & $\begin{array}{l}\text { 6. The first criterion: only education place; The second } \\
\text { measure: only Place employment; And third criteria: only } \\
\text { field of study. }\end{array}$ \\
\hline 7. Important criteria for the Master & $\begin{array}{l}\text { 7. The first criterion: only moral behavior; The second } \\
\text { measure: } 75 \% \text { of relaition dimensions - and } 25 \% \text { of moral } \\
\text { behavior; And third criteria: } 50 \% \text { of Relations between } \\
\text { teachers and students - and } 50 \% \text { of moral behavior. }\end{array}$ \\
\hline $\begin{array}{l}\text { 8. Measures to meet the expectations of superiors and } \\
\text { colleagues and students and the scientific community }\end{array}$ & $\begin{array}{l}\text { 8. } 50 \% \text { of moral behavior }-50 \% \text { of Research - scientific } \\
\text { dimensions. }\end{array}$ \\
\hline
\end{tabular}

University of Faculty of Humanities

Masters teaching quality examination result with look of up to down (base sciences collegiate, collegiate chief)

Result 45 - very good participate in collegiate didactic activities ,very good participate in collegiate research activities, very good cooperation with didactic adjutancy for cooperation didactic action acting, and, high participate in research - didactic activities in universities , very good acting in context of guidance \& scientific council, regarding arrangement, responsibility, very good assiduity belonging in comietion duties \& responsibilities .

Result 46 - establishment of relation with coworkers, establishment of good relation with students, observe superlative values \& professional, having well exceptionable, they are believer to regulation \& research didactic precept. 
Result 47 - didactic quality in idea of collegiate chief

\begin{tabular}{|l|l|}
\hline Variables & Components \\
\hline 1. Prioritization criteria groups & $\begin{array}{l}\text { 1. The first criterion: only Training dimensions; The second } \\
\text { measure: only Research dimensions; And third criteria: \%50 } \\
\text { of Research dimensions - and 50\% of Consultation } \\
\text { dimensions. }\end{array}$ \\
2. Prioritization criteria professors & $\begin{array}{l}\text { 3. The first criterion: only Training dimensions; The second } \\
\text { measure: only Research dimensions; And third criteria: only } \\
\text { Training dimensions. } \\
\text { 4. The first criterion: only Training dimensions; The second } \\
\text { measure: only moral behavior }\end{array}$ \\
\hline $\begin{array}{l}\text { 4. Scientific quality criteria } \\
\text { 5. Poor standards of teachers }\end{array}$ & $\begin{array}{l}\text { 5. The first criterion: only science dimensions; The second } \\
\text { measure: only facility dimensions. }\end{array}$ \\
\hline $\begin{array}{l}\text { 8. Measures to meet the expectations of superiors and } \\
\text { colleagues and students and the scientific community }\end{array}$ & 7. The first criterion: only cover dimensions \\
\hline
\end{tabular}

\section{Faulty of Humanities}

Masters teaching quality level with look of out (self researcher)

\section{Charts:}

\section{Students of the Faculty of Humanities}

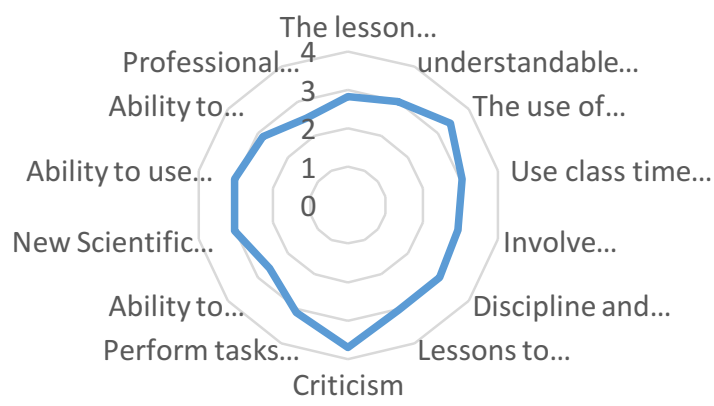

\section{Figure 1 - Assessment of the quality of instruction in terms of bottom-up (Students Faculty of} Humanities)

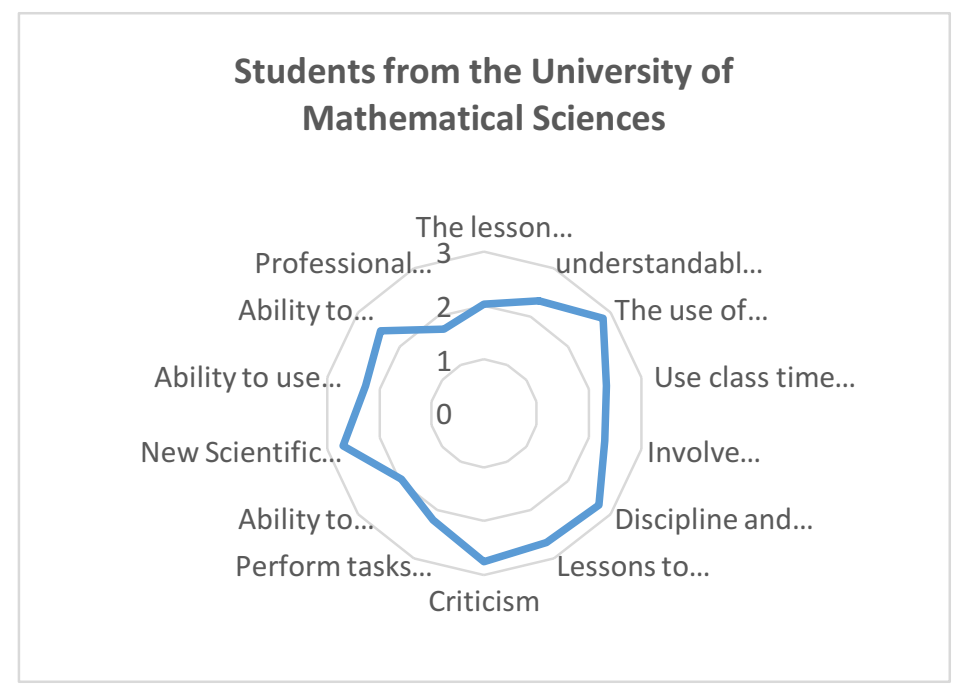

Figure 2 - Assessment of the quality of instruction in terms of bottom-up (Science Faculty) 
Students from the University of Basic

Sciences

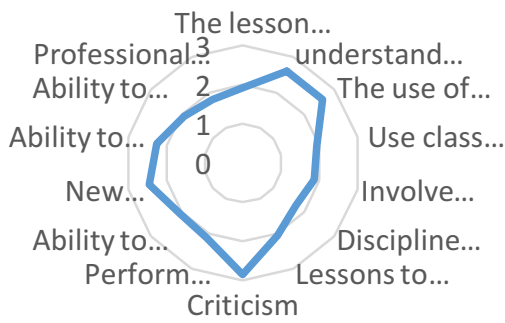

Figure 3. Assessment of the quality of instruction in terms of bottom-up (Students Faculty of Science)

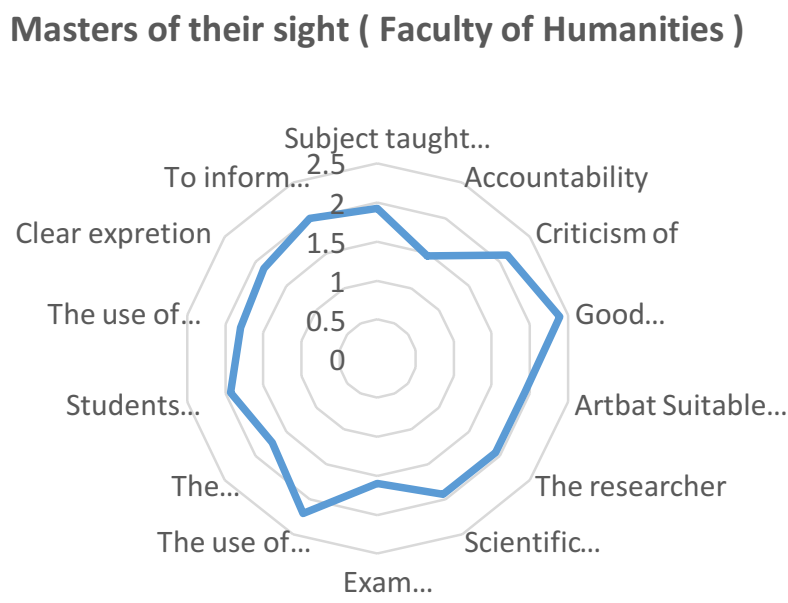

Figure 4 - Evaluation of the quality of instruction by looking from within (Faculty of Humanities)

From their perspective Teachers ( School of Mathematical Sciences )

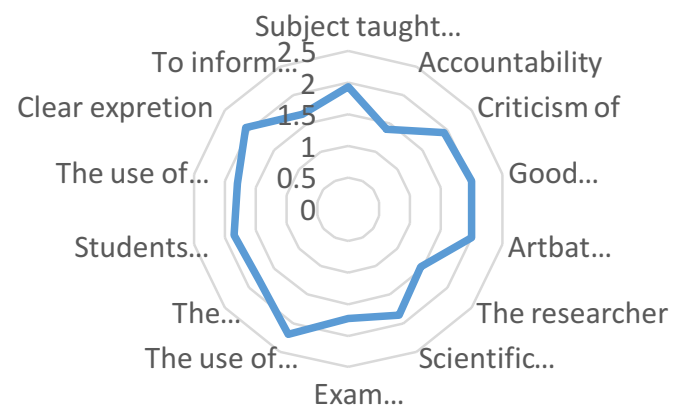

Figure 5 - Evaluation of the quality of instruction by looking from within (Faculty of Science) 


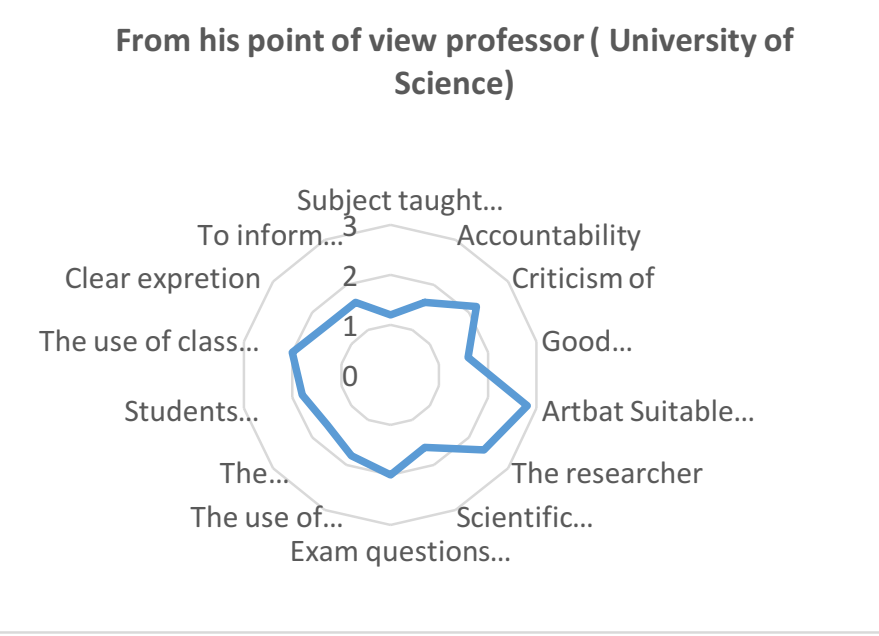

Figure 6 - Evaluate the quality of instruction by looking from within (Faculty of Science)

From the perspective of partners ( Faculty of Humanities )

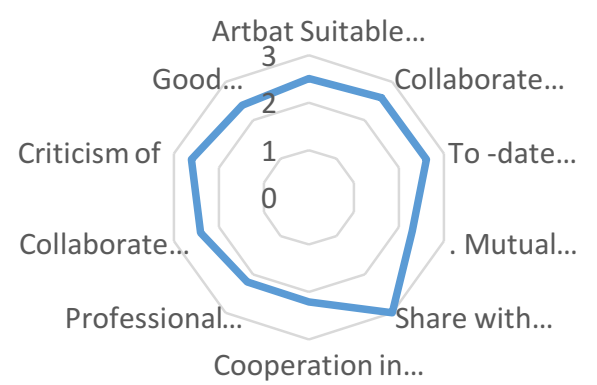

Figure 7 - Evaluate the quality of instruction by looking from the side (Faculty of Humanities)

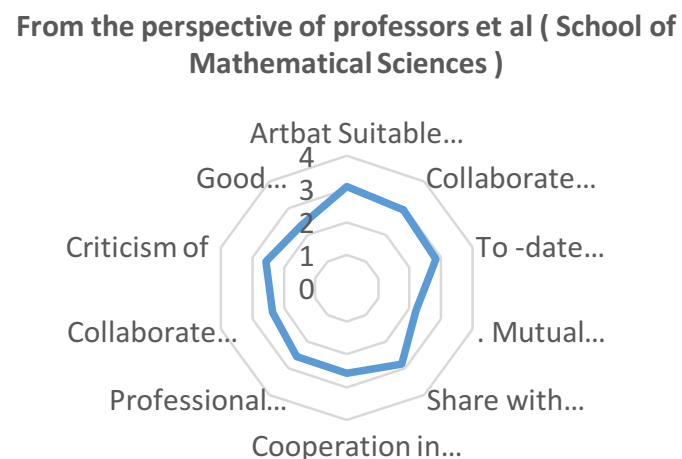

\section{Charts to evaluate the quality of instruction by looking from the side (School of Mathematical Sciences)}


From the perspective of academic partners ( University of Science))

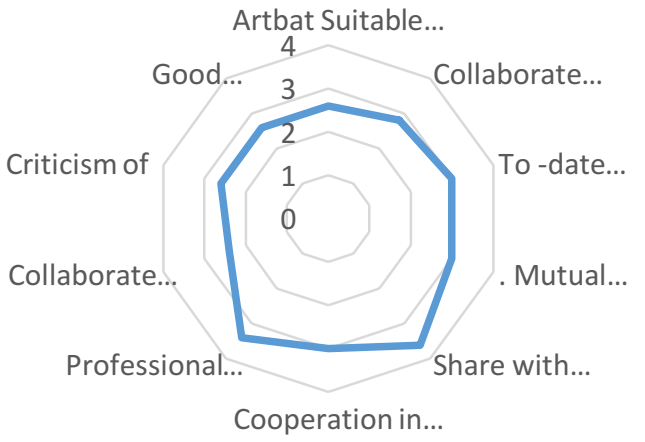

Figure 9 - assessing the quality of instruction by looking from the side (Faculty of Science)

Chart 10 - Evaluation of the quality of instruction by looking from top to bottom (Vice Faculty of Humanities)

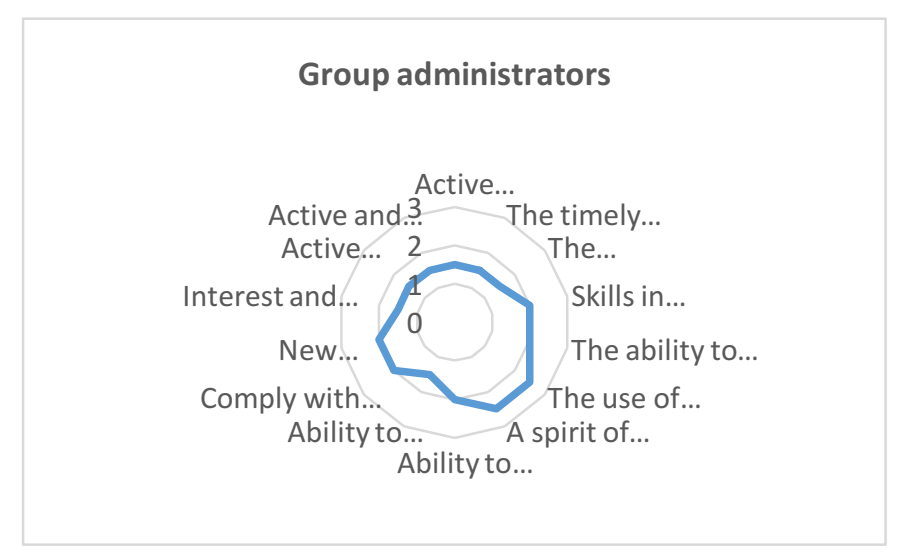

Figure 11 - to evaluate the quality of instruction by looking from top to bottom ( the heads of the Faculty of Humanities ) 
From the perspective of Dean

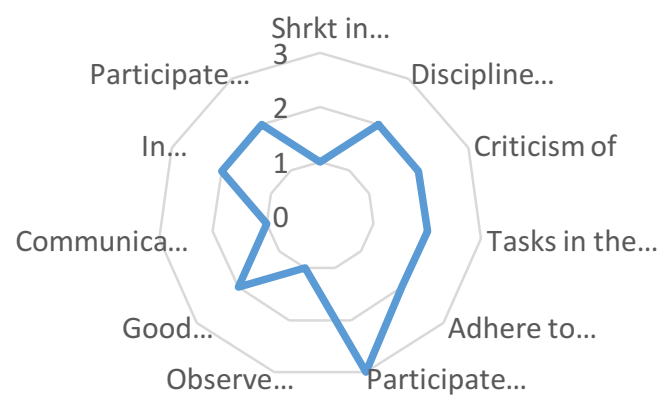

Figure 12 - to evaluate the quality of instruction by looking from top to bottom ( Dean of the Faculty of Science )

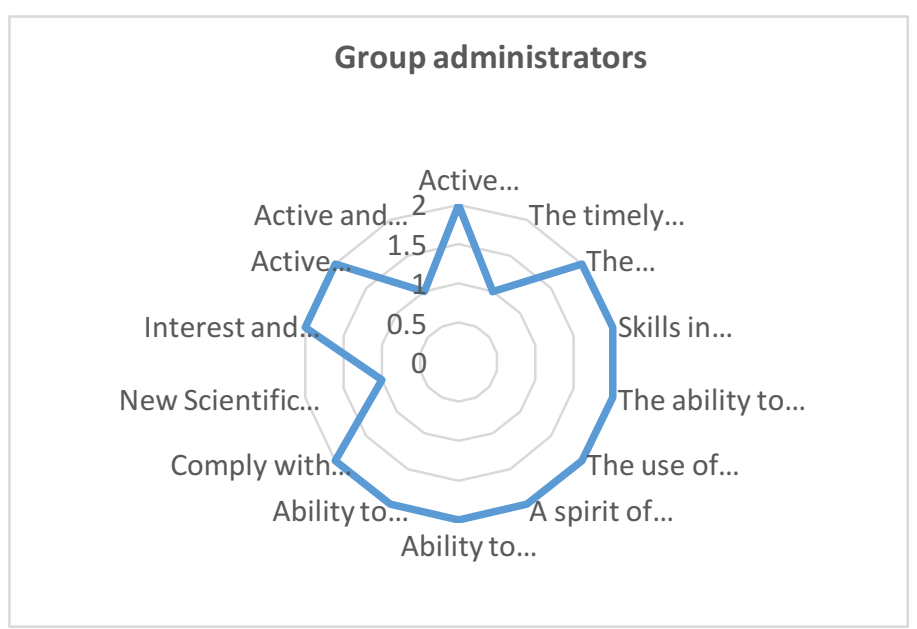

13. The assessment of the quality of instruction by looking at the graph from top to bottom ( Director of the School of Mathematical Sciences )

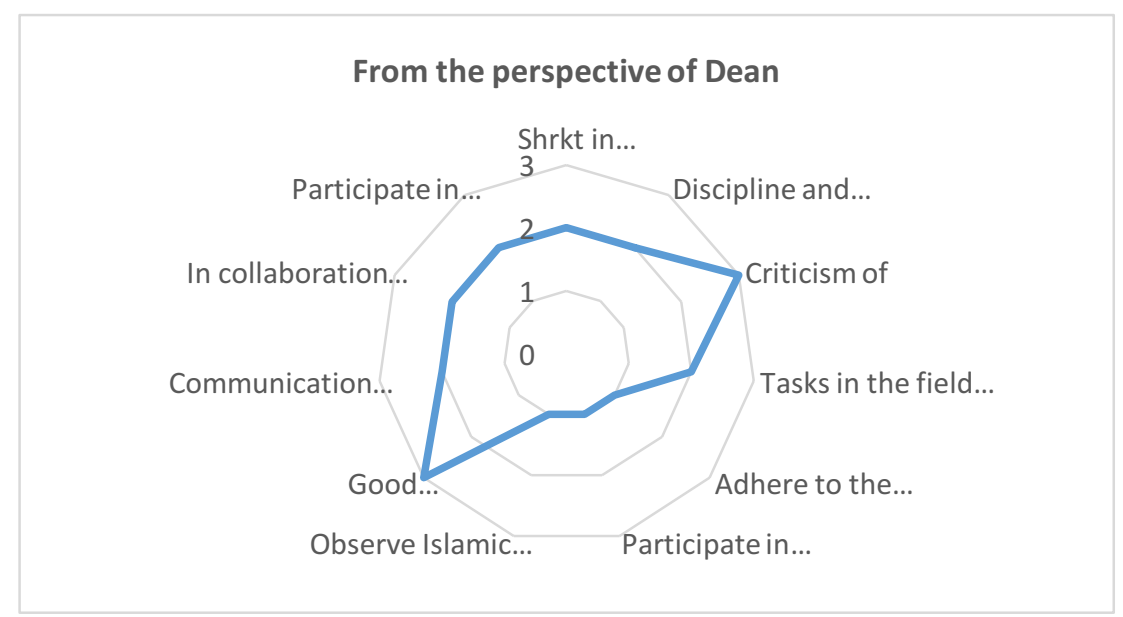

14. The assessment of the quality of instruction by looking at the graph from top to bottom (Dean of the Faculty of Science)

\section{References}

Bitarfpour, Mohammad Hasan." Evaluation ( feedback ) 360 impact on improving the performance of management and organization", Andishe saraye Taavon; 2014 
John way, jonz; Viliyam Berli, " 360 degree feedback strategies, approaches and ways for managers" , translate by Asghar pour , Esmaeil ; Taleghani, Gholamreza ; Sopko Press; 2001

Chang, Geloriya, Introducing 360-degree performance evaluation service organizations, translate by Zare Eshkazi, Jalaleddin, Misbah Quarterly, Year IX, Issue 36; 2002

Doulan, Sholer, Rendal S; Personnel management and human resources, translate by Tousi, Mohammad Ali, Saebi, Mohammad, Tehran, State Management Training Center, Fourth Edition, 2000.

Ghorbani, Mahmood; Keramati. Mohammad Reza; Jafarian Rad , Mohammad Jafar; Evaluating employee performance, Mashhad, Toos research publications, 2003.

Mirchi, Mandana; 360-degree evaluation, the newspaper world economy; No. 2036, 2010.

Iran Khodro Education Center, 360-degree assessment theory and practice. Tehran , Iran Khodro training center , 2006

Musharraf Javadi and Mohammad Hussein, the role of performance evaluation approach 360 degrees in organizational effectiveness.

Nasrjvahry born , J. mihrabs , F Bazvand , " compared to the traditional method of performance assessment and 360-degree feedback Lorestan University of Medical Sciences and its relationship with employee satisfaction ", Journal of Management Development and Transformation, page 57, 2011.

. Byars, L.I \& Rue, L.W. (2008). Human Resource Management: 9 Th Edition. New York: Mc GrawHill.

USING 360 FEEDBACK AND THE INTEGRAL MODEL TO DEVELOP LEADERSHIP”, (CACIOPPE.R, (1999)

MACCARTY.M AND TOMAAS N CARAVAN (2001), 360 FEEDBACK AND PROCCASS: PERFORMANCE IMPROVEMENT AND EMPLOYEE CAREER DEVELOPMENT", JOURNAL OF EUROPEAN INDUSTRIAL TRAINING, PP.5-3

Snell, S. A \& Bohlander, G. W. (2007). Managing Human Resources. Thomson Publishing Company. 